\title{
Kendala Siswa SMK dalam Pembelajaran Daring Matematika di Situasi Pandemi COVID-19
}

\author{
Rinrin Nur Tasdik ${ }^{1}$, Risma Amelia ${ }^{2}$ \\ ${ }^{1,2}$ Program Studi Pendidikan Matematika, Fakultas Ilmu Pendidikan, Institut Keguruan dan Ilmu Pendidikan, \\ Jl. Terusan Jendral Sudirman, Cimahi, Indonesia \\ rinrintasdik@gmail.com
}

\begin{abstract}
The Covid-19 pandemic has had many impacts on activities of daily life, one of which is in the world of education. The government prohibits all crowd activities, therefore teaching and learning activities are changed to Online. But in practice there are many obstacles and obstacles experienced by students and teachers when the learning process takes place, especially in mathematics learning. The purpose of this study was to determine the obstacles or constraints experienced by students when learning online. The method used is descriptive qualitative, the data collection technique is done by providing an online questionnaire. The location is used as an observation at the Bojongsoang Health Vocational School. The observation subjects of this study were students at the SMK equivalent level in class X and XII. Based on the analysis of the data from the questionnaire, it was found that the obstacle factors in learning mathematics online were: Difficult and bored, ineffective, internet quota that runs out easily, and unstable internet network.
\end{abstract}

Keywords: Covid-19, Online Learning, Mathematics, Obstacles

\begin{abstract}
Abstrak
Pandemi Covid-19 banyak berdampak pada aktivitas kehidupan sehari-hari salah satunya di dunia pendidikan. Pemerintah melarang segala aktivitas yang bersifat kerumunan, oleh karenanya aktivitas belajar mengajar dirubah menjadi secara Daring. Tetapi didalam praktiknya banyak kendala maupun hambatan yang dialami siswa maupun guru saat proses pembelajaran berlangsung khususnya pada pembelajaran Matematika. Tujuan penelitian ini adalah untuk mengetahui hambatan atau kendala yang dialami siswa ketika pembelajaran Daring. Metode yang digunakan adalah kualitatif deskriptif, teknik pengumpulan data dilakukan dengan memberikan kuesioner online. Lokasi yang dijadikan observasi di SMK Kesehatan Bojongsoang. Subjek observasi penelitian ini adalah siswa pada jenjang SMK Sederajat di kelas X dan XII. Berdasarkan analisis data dari kuesioner, didapatkan hasil bahwa faktor hambatan pembelajaran daring matematika, yaitu: Sulit dan bosan, kurang efektif, kuota internet yang mudah habis, jaringan internet yang tidak stabil.
\end{abstract}

Kata kunci: Covid-19, Pembelajaran Daring, Matematika, Kendala

Copyright (c) 2021 Rinrin Nur Tasdik, Risma Amelia

$\triangle$ Corresponding author: Rinrin Nur Tasdik

Email Address: rinrintasdik@gmail.com (Jl. Terusan Jendral Sudirman, Cimahi, Indonesia)

Received 10 Desember 2020, Accepted 15 Maret 2021, Published 16 Maret 2021

\section{PENDAHULUAN}

Pendidikan merupakan suatu hal yang sangat penting untuk setiap generasi dan kemajuan bangsa. Implementasi pendidikan untuk setiap generasi salah satunya dituangkan dalam suatu sistem yang bernama sekolah. Sekolah memfasilitasi setiap generasi untuk menjadi generasi yang unggul dengan pembelajaran yang menunjang untuk kemajuan generasi. Sekolah bersifat wajib karena peran penting sekolah yang menghasilkan ilmu pengetahuan dan prilaku yang baik. Sistem didalam sekolah melatih peserta didik untuk selalu disiplin dengan datang kesekolah tepat waktu dan tertib dari mulai jam 07.00 WIB sampai jam 12.00 atau bahkan ada yang sampai jam 15.00. Kemudian pada saat sekolah peserta didik bisa berinteraksi dengan guru dan juga peserta didik lain yang bisa meningkatkan rasa sosialisme didalam diri siswa. Tetapi semua hal itu terasa berbeda dengan adanya musibah pandemi Covid-19. 
Pada saat ini dunia sedang berjuang melawan Coronavirus Diseases 2019 atau disingkat Covid19. Coronavirus merupakan keluarga besar virus yang menyebabkan penyakit pada manusia dan hewan. Pada manusia biasanya menyebabkan penyakit infeksi saluran pernapasan, Covid-19 dapat menyebabkan gejala ringan termasuk flu, sakit tenggorokan, batuk, dan demam (Kementrian Kesehatan, 2019). Covid-19 dapat menular dan dengan cepat telah meyebar ke berbagai negara. Lebih dari 200 negara telah terpapar virus ini, hal tersebut tentu memberi imbas sangat besar kepada setiap negara termasuk di Indonesia. Salah satunya dalam bidang pendidikan. Untuk memutuskan penyebaran Covid-19 pemerintah Indonesia melalui Kementrian Pendidikan dan Kebudayaan dan Kementrian Agama RI, menerapkan kebijakan belajar dan bekerja dirumah (Work From Home) mulai pertengahan Maret 2020. Namun meskipun dimasa pandemi ini Kemendikbud tetap menegaskan bahwa pendidikan merupakan hal yang wajib.

Pendidikan adalah suatu hal yang sangat penting dalam kehidupan setiap manusia, pendidikan diturunkan dari satu generasi ke generasi berikutnya melalui berbagai aspek yaitu pengajaran, penelitian maupun pelatihan. Disamping pendidikan berperan penting dalam berbagai hal namun pada kenyataannya masih banyak orang menyalah artikan tentang pendidikan. Sebagian orang menganggap pendidikan adalah hal yang lumrah dan sebagian lagi karena menganggap pendidikan sangatlah penting sehingga banyak dari mereka yang hanya ingin memperoleh nilai tinggi dan gelar saja. Padahal tujuan dari pendidikan ialah mengetahui hal yang tidak tahu menjadi tahu dan pendidikan juga bisa menjadi wadah untuk proses perubahan karakter dari yang tidak baik menjadi baik. Tujuan pendidikan disebut juga dalam Undang-Undang No. 20 Tahun 2003 dalam pasal 3 adalah sebagai berikut "Pendidikan bertujuan untuk berkembangnya potensi peserta didik agar menjadi manusia yang beriman dan bertakwa kepada Tuhan Yang Maha Esa, berakhlak mulia, sehat, berilmu, cakap, kreatif, mandiri, dan menjadi warga negara yang demokratis serta bertanggung jawab (UU 2003 No 20 Sistem Pendidikan Nasional, 2003). Dari karakter tujuan pendidikan tersebut kita bisa menerapkannya sebagai bahan evaluasi untuk melihat sejauh mana ketercapaian setiap hal yang ada di tujuan pendidikan tersebut. Menurut H. Fuad Ihsan menjelaskan bahwa pengertian yang sederhana dan umum makna pendidikan sebagai "Usaha manusia untuk menumbuhkan dan mengembangkan potensi-potensi pembawaan baik jasmani maupun rohani sesuai dengan nilai-nilai yang ada didalam masyarakat dan kebudayaan". Usaha-usaha yang dilakukan untuk menanamkan nilai-nilai dan normanorma tersebut serta mewariskan kepada generasi berikutnya untuk dikembangkan dalam hidup dan kehidupan yang terjadi dalam suatu proses pendidikan sebagai usaha manusia untuk melestarikan hidupnya (Ihsan, 2005). Disamping itu Jhon Dewey menjelaskan bahwa pendidikan adalah proses pembentukan kecakapan-kecakapan fundamental secara intelektual dan emosional kearah alam dan sesama manusia (Dewey, 2003). Tetapi melihat kondisi Wabah Covid-19 yang terus meningkat ini perlu adanya inovasi pembelajaran yang dapat membuat pembelajaran bisa terus berjalan.

Kondisi ini membuat para pemerhati pendidikan merancang berbagai metode pendidikan jarak jauh. Selain itu pandemi ini juga memaksa untuk terus berinovasi khususnya dalam teknologi 
pendidikan dan memanfaatkannya untuk proses pembelajaran (T. T. Sari \& Cahyono, 2020). Hal ini dilakukan agar para pelaksana pendidikan memiliki berbagai macam alternatif cara dalam memberikan pembelajaran kepada peserta didik (Ramanta \& Dwi Widayanti, 2020). Dengan begitu pembelajaran daring menjadi solusi untuk menghadapi permasalah tersebut. Pembelajaran daring merupakan sebuah pembelajaran yang dilakukan dalam jarak jauh melalui media berupa internet dan alat penunjang lainnya seperti telepon seluler dan komputer (Putria et al., 2020). Proses pembelajaran daring dirasa bisa menjadi solusi yang terbaik untuk saat ini, karena dirasa sangat aman, juga dapat dilakukan di rumah masing-masing, serta siswa dapat terus melaksanakan kewajibannya dalam proses belajar mengajarnya yang diawasi oleh orang tua/wali (T. T. Sari \& Cahyono, 2020). Menurut Setyorini keuntungan pembelajaran daring adalah waktu yang tidak terbatas, masih banyak waktu luang, menghemat biaya transfortasi (Setyorini, 2020). Berbagai aplikasi digunakan untuk menunjang pembelajaran daring diantaranya Whatsapp, Zoom Meeting, Google Clasroom, Edmodo, dan lain sebagainya. Pembelajaran daring juga bisa dilakukan melalui video pembelajaran yaitu siswa dapat melakukan pembelajaran secara online seperti memahami materi pembelajaran dalam bentuk video pembelajaran yang telah disiapkan oleh guru (Nuritha \& Tsurayya, 2021). Akan tetapi pada praktiknya pembelajaran daring ini tidak sebaik pembelajaran secara langsung khususnya pada pelajaran matematika.

Matematika adalah salah satu disiplin ilmu dalam dunia pendidikan yang memegang peranan penting dalam perkembangan sains dan teknologi (Salamah, 2014). Menurut Hidayat dalam bukunya mengungkapkan bahwa dengan belajar matematika siswa dapat berlatih menggunakan pikirannya secara logis, analitis, sistematis, kritis dan kreatif serta memiliki kemampuan bekerjasama dalam menghadapi berbagai masalah serta mampu memanfaatkan informasi yang diterimanya (Hidayat \& Yuliani, 2011). Manalu mengungkapkan bahwa Matematika adalah fundamental ilmu yang sangat penting untuk dimiliki oleh setiap orang agar terciptanya ketertiban dalam melakukan aktivitas keseharian (Manalu et al., 2020). Pendidikan matematika juga menciptakan berbagai inovasi untuk memajukan sistem pendidikan matematika di indonesia melalui metode, model yang lebih baik lagi sesuai dengan keadaan yang sedang terjadi. Karena pada dasarnya matematika sangatlah beriringan dengan kehidupan sehari-hari jadi sangat penting untuk melakukan pembaharuan sesuai dengan kondisi yang sedang terjadi. Tetapi terlepas dari itu matematika merupakan pelajaran yang masih dianggap sulit oleh para siswa (Pradana, 2016), dan juga pada kenyataannya masih banyak siswa yang tidak menyukai matematika karena menganggapnya sulit sehingga menyebabkan siswa enggan dan malas dalam belajar matematika (Friantini et al., 2020).

Oleh karena itu berdasarkan latar belakang diatas, peneliti tertarik untuk mengetahui kendala siswa SMK dalam pembelajaran daring khususnya pada pelajaran matematika dimasa pandemi ini. 
Kendala Siswa SMK dalam Pembelajaran Daring Matematika di Situasi Pandemi COVID-19, Rinrin Nur Tasdik, Risma Amelia

\section{METODE}

Jenis metode yang digunakan dalam penelitian ini adalah metode kualitatif deskriptif untuk bisa memberikan gambaran pembelajaran daring di SMK Kesehatan Bojongsoang, menurut Danim dalam bukunya mengungkapkan bahwa pada penelitian kualitatif data yang dikumpulkan umumnya berbentuk kata-kata, gambar-gambar, dan kebanyakan bukan angka-angka, kalaupun ada angka-angka sifatnya hanya sebagai penunjang (Danim, 2013). Sedangkan deskriptif adalah penelitian yang memiliki tujuan untuk mengetahui bagaimana kondisi dan keadaan objek/subjek yang diteliti dimana hasilnya dijelaskan dalam bentuk laporan penelitian (T. T. Sari \& Cahyono, 2020). Hubungan penelitian deskriptif dengan pendekatan kualitatif menggambarkan kegiatan penelitian yang dilakukan pada objek tertentu secara jelas dan sistematis dengan melakukan eksplorasi guna menerangkan dan memprediksi suatu gejala yang terjadi atas dasar data kualitatif yang diperoleh di lapangan (Hidajat et al., 2018). Teknik pengumpulan data dengan cara survey, yaitu dengan melakukan penyebaran kuesioner online, kuesioner online adalah teknik pengumpulan data secara online melalui formulir yang berisi beberapa pertanyaan yang harus dijawab oleh responden(I. K. Sari et al., 2020). Kuesioner tersebut dibagikan secara acak kepada responden melalui platform Google Form yang dikirimkan melalui pesan WhatsApp Group.

Analisis data menggunakan teknik statistika deskriptif. Statistika deskriptif merupakan teknik statistik yang digunakan untuk menganalisis data dengan cara mendeskripsikan atau menggambarkan data yang telah terkumpul sebagaimana adanya, tanpa bermaksud membuat kesimpulan yang berlaku secara umum (Sugiyono, 2008). Subjek penelitian ini adalah siswa kelas X dan XII di SMK Kesehatan Bojongsoang yang terdiri dari empat kelas yang berbeda yaitu kelas X Analis, X Farmasi, XII Analis, XII Farmasi. Jumlah responden yang telah mengisi kuesioner sampai batas waktu yang telah ditentukan adalah sebanyak 48 Siswa. Berikut pertanyaan yang diajukan dan data sebaran responden berdasarkan empat kelas yang berbeda.

Tabel 1. Pertanyaan yang Diajukan

\begin{tabular}{|l|l|}
\hline No. & \multicolumn{1}{|c|}{ Pertanyaan } \\
\hline 1 & Bagaimana menurutmu proses pembelajaran daring matematika \\
\hline 2 & Apakah proses pembelajaran daring matematika berjalan efektif \\
\hline 3 & $\begin{array}{l}\text { Sebutkan kendala apa saja yang kamu alami selama pembelajaran daring } \\
\text { matematika }\end{array}$ \\
\hline 4 & Harapan apa untuk pembelajaran daring matematika kedepannya \\
\hline 5 & Sistem Pembelajaran matematika yang diharapkan \\
\hline
\end{tabular}

Tabel 2. Sebaran Responden yang Mengisi Kuesioner

\begin{tabular}{|r|l|c|c|}
\hline No & \multicolumn{1}{|c|}{ Kelas } & Jumlah Siswa & Persentase \\
\hline 1 & X Analis & 9 & $19 \%$ \\
\hline 2 & X Farmasi & 17 & $35 \%$ \\
\hline 3 & XII Analis & 4 & $8 \%$ \\
\hline 4 & XII Farmasi & 18 & $38 \%$ \\
\hline \multicolumn{2}{|l|}{ Jumlah } & 48 & $100 \%$ \\
\hline
\end{tabular}




\section{HASIL DAN DISKUSI}

Hasil penelitian ini menunjukkan bahwa siswa mengalami kesulitan dalam pembelajaran daring matematika dikarenakan berbagai faktor. Faktor-faktor tersebut diantaranya banyak siswa yang merasa bosan dan sulit dengan kondisi pembelajaran daring matematika karena proses pembelajarannya kurang menarik dan monoton. Kemudian penjelasan materi dari guru yang tidak dapat dipahami oleh siswa ditambah pembelajaran matematika yang sangan sulit. Lalu selain kendala dari proses pembelajarannya, siswa mengalami kesulitan dalam sistem pembelajarannya yang harus menggunakan internet, hal tersebut mengharuskan siswa untuk selalu menyiapkan kuota dan sinyal kuota untuk belajar, tetapi siswa masih ada yang belum mampu untuk menyiapkan hal tersebut. Banyak siswa yang lebih memilih untuk pembelajaran luring daripada pembelajaran daring karena dirasa bisa lebih efektif dan tidak ribet dalam proses pembelajaran.

Berdasarkan hasil penelitian ditemukan beberapa fakta informasi terkait kondisi pembelajaran daring matematika pada praktiknya. Data tersebut diperoleh dari hasil kuesioner yang telah disebar secara acak pada empat kelas yang berbeda. Berikut ini merupakan pembahasan dari hasil yang diperoleh dari kuesioner yang diberikan :

\section{Kondisi Pembelajaran Daring}

Dari hasil pengumpulan data kuesioner No. 1 tentang "Bagaimana menurutmu proses pembelajaran daring matematika ?". Dari pertanyaan tersebut didapat hasil sebagai berikut :



Gambar 1. Kondisi Pembelajaran Daring Matematika

Pada gambar 1, terlihat bahwa responden yang menjawab sulit/ribet/membosankan sebanyak 38\% beberapa siswa berpendapat bahwa suasana pembelajaran daring yang hanya berinteraksi lewat virtual ataupun lewat pesan online dengan durasi yang lumayan lama membuat siswa menjadi bosan dan juga melelahkan mata, ditambah pelajaran matematika yang sulit untuk dipahami membuat siswa menjadi tidak bersemangat dalam belajar. kemudian yang menjawab kurang baik sebanyak $28 \%$ penyebabnya karena siswa merasa pembelajaran daring matematika sangat sulit untuk dipahami bahkan ketika pembelajaran di sekolah pun matematika menjadi pelajaran yang kurang disenangi apalagi saat pembelajaran daring siswa merasa kurang baik. lalu yang menjawab cukup dan baik sama-sama 
sebanyak $17 \%$ alasannya pembelajaran daring membuat pembelajaran lebih efisien dengan tidak perlu pergi ke sekolah dan juga bisa aman dari penyebaran virus Covid-19. Bisa diartikan bahwa pembelajaran daring ini menghambat siswa dalam proses pembelajaran dibuktikan dengan $67 \%$ siswa yang merasa tidak baik dengan pembelajaran daring ini karena dirasa sangat membosankan dan sulit untuk memahami pelajaran apalagi pelajaran matematika. Hal ini sejalan dengan penelitian yang dilakukan oleh Ruci Pawicara, faktor-faktor peserta didik yang mengalami kejenuhan belajar daring dikarenakan materi kurang menarik, pembelajaran yang monoton, dan pemberian materi tanpa penjelasan mendalam. Hal tersebut menimbulkan ketidakpahaman materi, akibatnya timbul rasa malas, kehilangan semangat, lelah, dan bosan terhadap materi pembelajaran matematika (Pawicara \& Conilie, 2020). Selain itu, menurut Mustakim dalam penelitiannya penggunaan handphone dengan durasi yang sangat lama dan intensitas yang terlalu sering karena mengerjakan tugas dan bermain sosial media mengakibatkan siswa mengalami keluhan fisik berupa kelelahan mata sebanyak 53\%, lalu sakit kepala 33\%, gampang mengantuk 33\%, sulit istirahat $20 \%$ dan keluhan lainnya seperti demam, sesak nafas, dan badan pegal sebanyak 13\% (Mustakim, 2020).

\section{Pandangan Siswa Terhadap Keefetifan Pembelajaran Daring Matematika}

Berdasarkan hasil pengumpulan data kuesioner No. 2 tentang "Apakah proses pembelajaran daring matematika berjalan efektif?". Dari pertanyaan tersebut didapat hasil sebagai berikut:

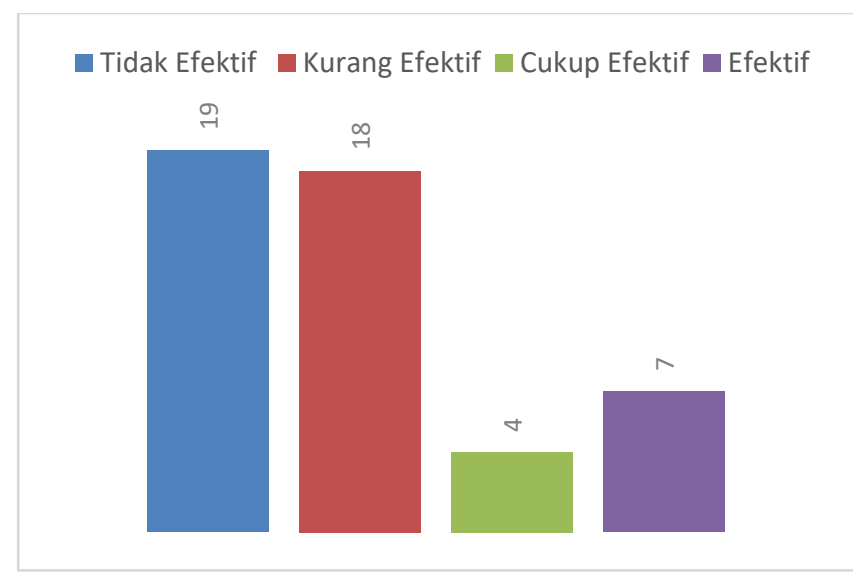

Gambar 2. Keefektifan Pembelajaran Daring

Pada gambar 2. Didapat hasil bahwa siswa yang merasa pembalajaran daring ini tidak efektif sebanyak $40 \%$ alasannya banyak siswa yang ingin langsung dibimbing oleh gurunya karena ketika dibimbing lewat virtual ataupun pesan online terkadang banyak terjadi salah paham apa yg disampaikan guru dengan apa yang dipahami oleh siswa sehingga menyebabkan kesalahpahaman yang berakibat pembelajaran tidak dimengerti siswa, kemudian yang merasa kurang efektif sebanyak $38 \%$ siswa merasa pelajaran matematika tidak cocok dijelaskan lewat pembelajaran daring karena sulitnya memahami pelajaran matematika, lalu yang merasa cukup efektif sebanyak $8 \%$ dan yang merasa pembelajaran daring ini efektif sebanyak $14 \%$ alasannya siswa merasa dengan pembelajaran daring ini siswa bisa lebih fokus belajar di rumah dan lebih aman dari penyebaran virus Covid-19. 
Dapat disimpulkan bahwa pembelajaran daring matematika ini tidak dan kurang efektif, persentase siswa yang menjawab tidak efektif dan kurang efektif sebanyak 77\%. Hal ini sejalan dengan hasil penelitian yang dilakukan oleh Yuliana Alfiyati, dkk yang menyatakan bahwa pembelajaran daring ini kurang efektif karena kurangnya komunikasi sehingga menurunnya prestasi siswa sehingga dinilai pembelajaran daring tidak efektif dalam pelaksanaan belajar mengajar (Alfiyatin et al., 2020).

\section{Kendala dan Hambatan Pembelajaran Daring Matematika}

Berdasarkan hasil pengumpulan data kuesioner No. 3 tentang "Sebutkan kendala apa saja yang kamu alami selama pembelajaran daring matematika?". Dari pertanyaan tersebut didapat hasil sebagai berikut :



Gambar 3. Kendala dan Hambatan Pembelajaran Daring

Pada gambar 3, dapat diinterpretasikan bahwa faktor penghambat dari pembelajaran daring ini adalah kuota internet yang mudah habis dikarenakan harus menggunakan video konferensi Zoom Meeting yang mengakibatkan kuota internet cepat habis, kemudian kestabilan jaringan internet yang kurang baik akibatnya siswa kurang menyerap materi yang disampaikan oleh gurunya dibuktikan dengan persentase siswa yang mengeluh dengan kendala tersebut sebanyak $75 \%$. Selain itu, siswa susah memahami isi materi terutama pada pelajaran matematika, siswa merasa saat kondisi pembelajaran normal pelajaran ini sulit untuk dipahami ditambah ketika pembelajaran daring ini siswa jadi lebih sangat sulit untuk memahami materi. Hal ini senada dengan penelitian yang dilakukan oleh Huwaina Nabila dan Dwi Sulistiyaningsih yang menyatakan bahwa siswa mengalami kendala terkait signal internet yang kurang memadai, sehingga siswa kesulitan dalam proses pembelajaran daring, karena kuat lemahnya signal berpengaruh terhadap jalannya pembelajaran, seperti ketika siswa kesulitan bergabung pada ZoomMeeting, atau video ngelag, dan lain-lain nya yang berakibat pada ketidak maksimalan pembelajaran (Nabila \& Sulistiyaningsih, 2020). Selain itu, menurut Agusmanto dalam penelitiannya menuturkan bahwa hasil wawancara yang dilakukan kepada siswa hampir seluruhnya menjawab lambatnya jaringan internet ditempat mereka menjadi kendala dalam proses pembelajaran, karena mayoritas responden berada pada pedesaan. Kemudian banyak siswa yang mengaku lebih sulit memahami materi pelajaran dengan pembelajaran daring dibandingkan dengan pembelajaran tatap muka, karena kurangnya kesempatan untuk berdiskusi secara langsung dan bebas dengan dosennya (Hutauruk \& Sidabutar, 2020). 


\section{Harapan Perbaikan Pembelajaran Daring Matematika}

Berdasarkan hasil pengumpulan data kuesioner No. 4 tentang "Harapan apa untuk pembelajaran daring matematika kedepannya?”. Dari pertanyaan tersebut didapat hasil sebagai berikut:

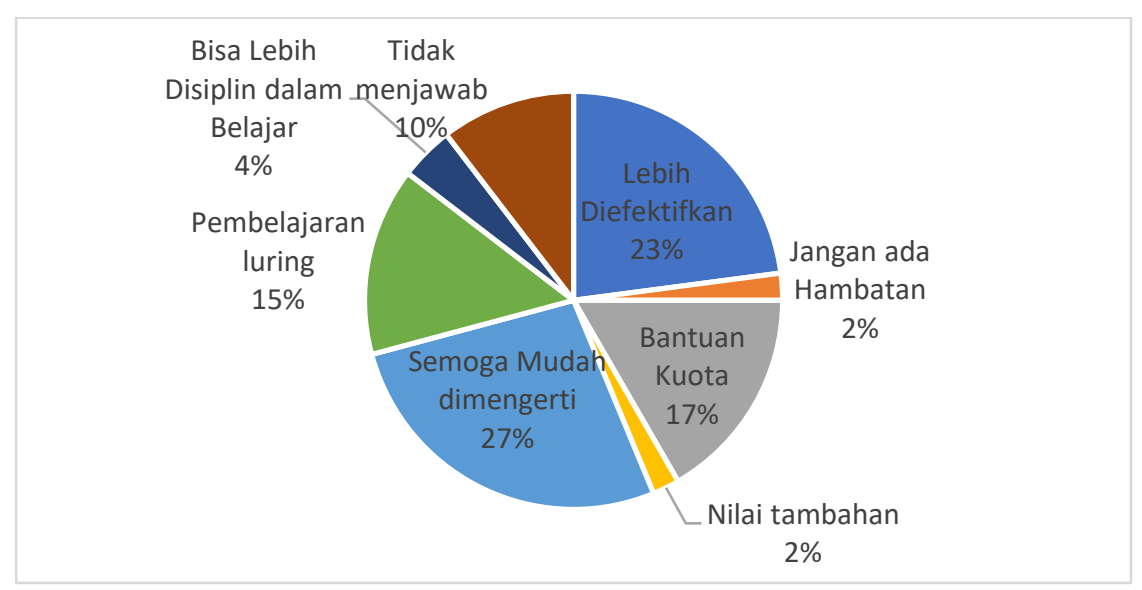

Gambar 4. Harapan Perbaikan Pembelajaran Daring

Pada gambar 4, terlihat bahwa siswa sangat mengharapkan pembelajaran daring matematika ini dimudahkan dan lebih diefektifkan kembali dengan persentase sebanyak 50\% hal ini senada dengan apa yang dikemukakan oleh Handayana bahwa upaya mengatasi masalah pembelajaran daring salah satunya dengan cara mendorong guru untuk kreatif dan inovatif dalam menciptakan pembelajaran daring yang menarik bagi siswa (Anugrahana, 2020). Lalu siswa juga mengharapkan ada bantuan kuota internet gratis dengan persentase siswa yang mengharapkan hal tersebut sebanyak $17 \%$ hal ini sejalan dengan survei yang dilakukan oleh Arus Survei Indonesia (ASI) yang menyatakan bahwa sebanyak $85 \%$ masyarakat mengharapkan program bantuan internet gratis dari pemerintah untuk meringankan beban ekonomi orang tua siswa/mahasiswa, karena hambatan utama pembelajaran daring ini adalah kuota internet (Rif'an, 2020). Dan ada beberapa siswa yang mengharapkan pembelajaran luring, kemudian bisa lebih disiplinkan kembali saat mengikuti pembelajaran, jangan memberikan hambatan kepada siswa seperti tugas yang banyak, dan juga ada siswa yang mengharapkan nilai tambah karena merasa pembelajaran yang penuh dengan perjuangan.

\section{Harapan Sistem pembelajaran Matematika Kedepannya}

Berdasarkan hasil pengumpulan data kuesioner No. 5 tentang "Pembelajaran matematika apa yang kamu harapkan kedepannya?". Dari pertanyaan tersebut didapat hasil sebagai berikut:

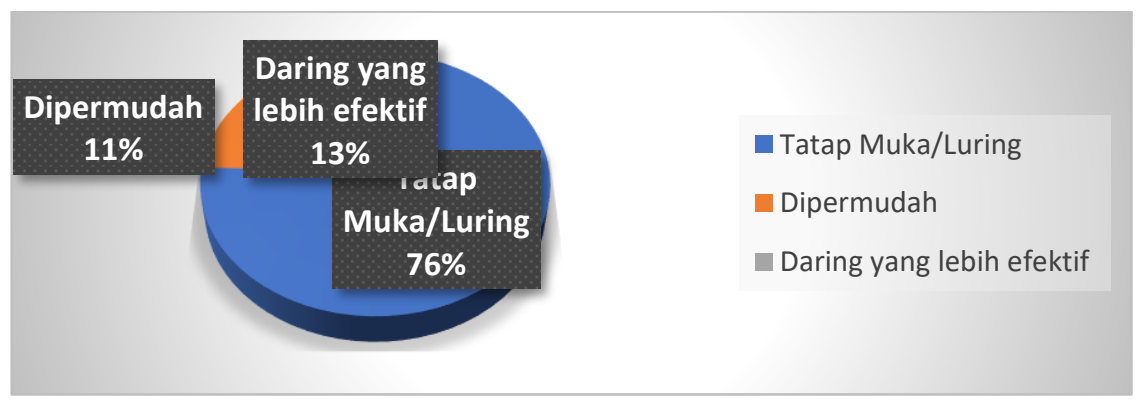

Gambar 5. Harapan Sistem Pembelajaran Kedepannya 
Pada gambar 5. Banyak siswa yang mengharapkan pembelajaran tatap muka/luring dengan persentase $76 \%$ karena suasana pembelajaran luring yang dapat berinteraksi langsung dengan guru dan teman-teman kelas yang membuat semangat belajar meningkat dan dapat dibimbing langsung oleh guru. Kemudian siswa menghapkan pembelajaran daring matematika yang lebih diefektifkan lagi dengan persentase $13 \%$ dengan alasan pembelajaran daring matematika memang dirasa kurang efektif tapi untuk mencegah penyebaran virus Covid-19 pembelajaran daring menjadi solusi terbaik untuk dilakukan, oleh karenanya siswa berharap pembelajaran daring ini lebih diefektifkan kembali seperti penyampaian materi yang mudah dimengerti siswa. Lalu yang terakhir siswa mengharapkan pembelajaran daring ini dipermudah dengan persentase sebanyak $11 \%$ karena terkadang guru memberikan tugas yang dirasa sulit dan juga banyak, siswa berharap pemberian tugas yang tidak memberatkan siswa. Dapat disimpulkan bahwa untuk kedepannya siswa mengharapkan pembelajaran luring atau pembelajaran tatap muka untuk bisa lebih memahami materi, bisa berdiskusi, dan bisa merasakan suasana sekolah pada umumnya. Selain itu siswa berharap jika pembelajaran luring tidak bisa dilakukan, maka pembelajaran harus lebih dipermudah dan lebih diefektifkan kembali. Hal ini senada dengan hasil penelitian (Mustakim, 2020) yang menyatakan bahwa meskipun peserta didik lebih banyak yang menyukai pembelajaran luring, namun mereka menerima kenyataan pembelajaran daring sebagai konsekuensi dari pemberlakuan work form home dari pemerintah dengan catatan pembelajaran daring harus lebih diefektifkan dan dipermudah dengan cara salah satunya pembelajaran dilakukan melalui video call, pemberian materi pembelajaran yang ringkas, meminimalisir mengirim materi dalam bentuk video berat untuk menghemat kuota, dll.

\section{KESIMPULAN}

Dalam pembelajaran daring matematika ini banyak siswa yang merasa bahwa pembelajaran daring dirasa sulit dan tidak efektif ditambah pelajaran matematika yang dianggap sulit. Terlihat dari pertanyaan pertama sebanyak $67 \%$ siswa menjawab bahwa pembelajaran daring ini tidak baik dan kurang baik karena siswa hanya berinteraksi lewat virtual ataupun chat dengan durasi yang lama, hal tersebut membuat mata cepat lelah dan juga membuat cepat bosan karena belajar seorang diri dan tidak ada bimbingan secara langsung dari guru. Kemudian pada pertanyaan kedua sebanyak $77 \%$ siswa menjawab pembelajaran daring matematika ini tidak efektif karena banyak siswa yang menganggap bahwa pembelajaran daring ini hanya efektif untuk beberapa mata pelajaran saja dan hanya dalam pengiriman tugas saja, yang lainnya merasa pembelajaran daring matematika ini tidak efektif karena materi pelajaran yang sulit dipahami. Pada pertanyaan ketiga, sebanyak $75 \%$ siswa mengeluh terhadap hambatan yang sering dialami saat proses pembelajaran daring matematika yaitu kuota yang mudah habis dan juga jaringan yang tidak stabil yang mengakibatkan susah memahami 
Kendala Siswa SMK dalam Pembelajaran Daring Matematika di Situasi Pandemi COVID-19, Rinrin Nur Tasdik, Risma Amelia

materi. Lalu pada pertanyaan keempat, sebanyak 50\% siswa mengharapkan pembelajaran yang dipermudah seperti pemberian tugas yang tidak sulit, tidak banyak, dan tidak membebani siswa dalam proses pembelajaran. Lalu lebih di efektifkan kembali pembelajaran secara daringnya seperti penggunaan aplikasi yang mudah diakses dan dapat membuat siswa lebih memahami materi, dan juga bantuan kuota internet yang sangat dibutuhkan siswa untuk menunjang proses pembelajaran daring. Dan pada pertanyaan terakhir, sebanyak $76 \%$ siswa mengharapkan pembelajaran secara luring karena suasana pembelajaran luring yang dapat berinteraksi langsung dengan guru dan teman-teman kelas yang membuat semangat belajar meningkat dan dapat dibimbing langsung oleh guru. Secara umum, siswa sudah tidak betah dengan pembelajaran daring ini dan sangat ingin melakukan pembelajaran tatap muka supaya bisa dibimbing langsung oleh gurunya dan juga bisa lebih paham terkait materi yang disampaikan apalagi pelajaran matematika yang sulit dipahami, selain itu bisa berdiskusi bersama teman-temannya di sekolah.

\section{UCAPAN TERIMA KASIH}

Ucapan terimakasih peneliti sampaikan kepada pihak-pihak yang telah membantu dalam penyususunan penelitian ini khususnya kepada Ibu Risma Amelia yang telah membimbing dalam penelitian ini, kemudian pihak sekolah SMK Kesehatan Bojongsoang yang telah memberikan izin untuk melakukan penelitian disekolah tersebut, dan juga kepada pihak Jurnal Cendikia yang telah memberikan kesempatan dalam mempublish jurnal penelitian ini.

\section{REFERENSI}

Alfiyatin, Y., Heriyanto, \& Nabila. (2020). Efektivitas Pembelajaran Daring Dalam Pandangan Siswa MI Al-Falah Dakiring-Bangkalan. STIT Al-Ibrohimy Bangkalan, 19(February), 1-33.

Anugrahana, A. (2020). Hambatan, Solusi dan Harapan: Pembelajaran Daring Selama Masa Pandemi Covid-19 Oleh Guru Sekolah Dasar. Scholaria: Jurnal Pendidikan Dan Kebudayaan, 10(3), 282-289. https://doi.org/10.24246/j.js.2020.v10.i3.p282-289

Danim, S. (2013). Menjadi Peneliti Kualitatif. CV Pustaka Setia.

Dewey, J. (2003). Dasar-dasar Ilmu Pendidikan. PT. Raja Grafindo Persada.

Friantini, R. N., Winata, R., \& Permata, J. I. (2020). Pengembangan Modul Kontekstual Aritmatika Sosial Kelas 7 SMP. Jurnal Cendekia: Jurnal Pendidikan Matematika, 4(2), 562-576. https://doi.org/10.31004/cendekia.v4i2.278

Hidajat, D., Pratiwi, D. A., \& Afghohani, A. (2018). Analisis Kesulitan dalam Penyelesian Permasalahan Ruang Dimensi Dua. Jurnal Pendidikan Matematika, 1(1), 1-16. https://doi.org/10.21043/jpm.v1i1.4452

Hidayat, W., \& Yuliani, A. (2011). Meningkatkan Kemampuan Berpikir Kritis Matematik Siswa Sekolah Menengah Atas Melalui Pembelajaran Kooperatif Think-Talk-Write ( TTW ). Matematika Dan Pendidikan Karakter Dalam Pembelajaran, 535-546.

Hutauruk, A., \& Sidabutar, R. (2020). Kendala pembelajaran daring selama masa pandemi di kalangan mahasiswa pendidikan matematika: Kajian kualiatatif deskriptif. Journal of Mathematics Education and Applied, 02(01), 45-51. 
Ihsan, F. H. (2005). Dasar-dasar Kependidikan. PT. Rineka Cipta.

UU 2003 No 20 - Sistem Pendidikan Nasional, (2003).

Kementrian Kesehatan. (2019). Informasi tentang Virus Corona (Covid-19). YSTC. https://stoppneumonia.id/informasi-tentang-virus-corona-novel-coronavirus/

Manalu, A. C. S., Manalu, S., \& Zanthy, L. S. (2020). Analisis Kesulitan Siswa SMP Kelas IX dalam Menyelesaikan Soal Materi Lingkaran. Jurnal Cendekia : Jurnal Pendidikan Matematika, 4(1), 104-112. https://doi.org/10.31004/cendekia.v4i1.179

Mustakim. (2020). Efektivitas Pembelajaran Daring Menggunakan Media Online Selama Pandemi Covid-19 Pada Mata Pelajaran Matematika the Effectiveness of E-Learning Using Online Media During the Covid-19 Pandemic in Mathematics. Al Asma: Journal of Islamic Education, 2(1), 112.

Nabila, H., \& Sulistiyaningsih, D. (2020). ANALISIS KESULITAN BELAJAR MATEMATIKA DALAM PEMBELAJARAN DARING BERBANTUAN MICROSOFT TEAMS KELAS XI SMA NEGERI 9 yang mempengaruhi signal, ketidak mampuan dalam pembelajaran online, interaksi selama proses pembelajaran, dan tugas dan bahan ajar dalam p. 62-71.

Nuritha, C., \& Tsurayya, A. (2021). Pengembangan Video Pembelajaran Berbantuan Geogebra untuk Meningkatkan Kemandirian Belajar Siswa. Jurnal Cendekia: Jurnal Pendidikan Matematika, 5(1), 48-64. https://doi.org/10.31004/cendekia.v5i1.430

Pawicara, R., \& Conilie, M. (2020). Analisis Pembelajaran Daring Terhadap Kejenuhan Belajar Mahasiswa Tadris Biologi Iain Jember di Tengah Pandemi Covid-19. ALVEOLI: Jurnal Pendidikan Biologi, 1(1), 29-38.

Pradana, P. H. (2016). Pengaruh Pembelajaran Kooperatif Tipe NHT \& STAD Dan Motivasi Belajar Terhadap Hasil Belajar Matematika. Jurnal Gammath, I(2), 9-17.

Putria, H., Maula, L. H., \& Uswatun, D. A. (2020). Analisis Proses pembelajaran Dalam Jaringan (DARING) Masa Pandemi COVID-19 pada Guru Sekolah Dasar. Jurnal Basicedu, 4(4), 861872. https://doi.org/10.31004/basicedu.v4i4.460

Ramanta, D., \& Dwi Widayanti, F. (2020). Pembelajaran Daring di Sekolah Menengah Kejuruan Putra Indonesia Malang pada Masa Pandemi COVID-19. Prosiding Seminar Bimbingan Dan Konseling, $O(0), 61-67$. http://conference.um.ac.id/index.php/bk2/article/view/81

Rif'an, A. (2020). Bantuan Internet Gratis Ringankan Beban Ekonomi. Arus Survei Indonesia (ASI). https://www.arussurvei.com/survei-asi-bantuan-internet-gratis-ringankan-beban-ekonomiartikel-ini-telah-tayang-di-rmol-id-dengan-judul-survei-asi-bantuan-internet-gratis-ringankanbeban-ekonomi-https-politik-rmol-id-r/

Salamah, F. (2014). Penerapan Strategi Pembelajaran Inquiry Untuk Peningkatan Pemahaman Konsep Matematika Pada Pokok Bahasan Logaritma. Jurnal Autentik, Vol.1, No.1, Januari 2017: 30-40, $1(1)$, $30-40$. https://www.academia.edu/33417375/._Penerapan_Strategi_Pembelajaran_Komunikatif?auto=d ownload

Sari, I. K., Nasriadi, A., Putri, B. Y., Tanggul, J., Aceh, K., \& Aceh, B. (2020). Kemampuan logis matematis siswa terhadap prestasi belajar untuk memprediksi peringkat kesuksesan nilai ujian bertaraf nasional 1, 2, 3. Jurnal Cendekia: Jurnal Pendidikan Matematika, 04(02), 468-479.

Sari, T. T., \& Cahyono, A. H. (2020). Pengembangan E-Learning Berbasis Android "Fun Math" Sebagai Alternatif Belajar Matematika Di Tengah Pandemi. Jurnal Cendekia: Jurnal Pendidikan Matematika, 04(02), 1283-1299. 
Kendala Siswa SMK dalam Pembelajaran Daring Matematika di Situasi Pandemi COVID-19, Rinrin Nur Tasdik, Risma Amelia

Setyorini. (2020). Terhadap Proses Pembelajaran Pada Kurukulum 13 ? Jiemar, 01(Juni), 95-102.

Sugiyono. (2008). Metode Penelitian Pendidikan (Pendekatan Kualitatif, Kuantitatif, dan R\&D). Alfabeta. 